\title{
IMPLEMENTASI KEBIJAKAN PENGENDALIAN KAWASAN BANDUNG UTARA DALAM PEMBUATAN IMB DI KECAMATAN CIMENYAN
}

\author{
Oneng Ruskasih ${ }^{1}$, Deasy Sylvia Sari², Ratna Meisa Dai ${ }^{3}$ \\ 1,2,3 Program Pascasarjana Kebijakan Publik \\ Fakultas Ilmu Sosial dan Ilmu Politik \\ Universitas Padjadjaran \\ onengruskasih@gmail.com
}

\begin{abstract}
ABSTRAK
Implementasi kebijakan pengendalian Kawasan Bandung Utara disingkat (KBU) dalam pembuatan Izin Mendirikan Bangunan disingkat (IMB) belum terlaksana secara menyeluruh. Masih banyak warga belum mempunyai IMB di Kecamatan Cimenyan. Tujuan dari penelitian adalah untuk mengetahui, mengkaji, menganalisis dan memahami secara mendalam tentang implementasi kebijakan Pemerintah Provinsi Jawa Barat Nomor 2 Tahun 2016 yaitu tentang Pedoman Pengendalian KBU. Metode implementasi kebijakan menggunakan pendekatan kualitatif melalui wawancara, dokumetasi dan observasi. Bagaimana implementasi kebijakan pengendalian KBU dalam pembuatan IMB di Kecamatan Cimenyan. Pemerintah Kabupaten perlu melaksanakan beberapa tindakan dalam pengendalian pembuatan IMB di Kecamatan Cimenyan. Adapun langkah-langkah yang dapat dilakukan adalah mengoptimalkan kinerja sumber daya manusia, penyediaan anggaran dan kerjasama antar pihak pemerintah, swasta dan masyarakat. Implementasi kebijakan akan terlaksana apabila sosialisasi tentang IMB secara menyeluruh. Faktor penyebab kesulitan warga karena perizinan harus melalui Pemerintah Provinsi sehingga mengakibatkan waktu yang cukup lama dalam pembuatan IMB. Akan lebih baik jika aturan pembuatan IMB dipermudah khusus pemohon IMB yang luas lahannya terbatas, melalui aturan yang dikeluarkan oleh Pemerintah Kabupaten atau Pemerintah Provinsi.
\end{abstract}

\section{Kata Kunci: Implementasi, Kebijakan Publik, IMB, KBU.}

\begin{abstract}
The implementation of the control policy for the abbreviated North Bandung Area (KBU) in making the abbreviated Building Permit (IMB) has not been implemented comprehensively. There are still many residents who do not have an IMB in Cimenyan District. The purpose of the research is to find out, examine, analyze and understand in depth about the implementation of the West Java Provincial Government's policy Number 2 of 2016 which is about the KBU Control Guidelines. The policy implementation method uses a qualitative approach through interviews, documentation and observation. How is the implementation of KBU control policies in making IMB in Cimenyan District. The district government needs to carry out several actions in controlling the manufacture of IMB in Cimenyan District. The steps that can be taken are optimizing the performance of human resources, providing budget and cooperation between the government, the private sector and the community. Policy implementation will be carried out if there is a thorough socialization of the IMB. The factor that causes difficulties for residents is that licensing must go through the Provincial Government, resulting in a long time in making the IMB. It would be better if the rules for making IMBs were made easier, especially for IMB applicants with limited land area, through regulations issued by the Regency Government or Provincial Government.
\end{abstract}

Keywords: Implementation, Public Policy, IMB, KBU. 


\section{PENDAHULUAN}

Masalah pembuatan Ijin Mendirikan Bangunan terutama di Kawasan Bandung Utara menjadi perhatian pemerintah terkait terjadinya lahan hijau daerah Bandung Utara yang terus dibangun perumahan dan gedunggedung sehingga merusak tatanan kawasan hijau. Banyak diantara bangunan tersebut yang tidak memiliki Izin Mendirikan Bangunan (IMB), serta banyak nya pelanggaran, yang akhirnya keluar Peraturan Daerah Provinsi Jawa Barat Nomor 2 Tahun 2016 tentang Pedoman Pengendalian Kawasan Bandung Utara sebagai Kawasan Strategis Provinsi Jawa Barat. Permasalahan yang muncul di Kecamatan Cimenyan masih banyak masyarakat yang belum memiliki IMB dengan berbagai alasan menyebabkan Kawasan Bandung Utara (KBU) banyak yang mendirikan bangunan tanpa IMB bahkan bangunan sudah jadi dan ditempati sejak lama tidak mempunyai IMB karena merasa memiliki ahan turun temurun dan untuk membuat Ijinnya suasah.

Hal ini memerlukan perhatian sangat serius untuk Pemerintah agar masyarakat tertib dalam aturan untuk membuat Ijin Mendirikan Bangunan serta mensosialisasikan kepada masyarakat untuk mengurangi pembangunan di area tersebut. Kawasan Bandung Utara merupakan kawasan yang berada diwilayah Kecamatan Cimenyan. Dari dulu kawasan ini bertujuan membentuk suatu daerah yang memiliki banyak tumbuhan hijau bahkan akan menjadikan sebuah kawasan pertanian, pemukiman warga dan pedesaan.

Kawasan ini mencakup wilayah pengelolaan pertanian serta wilayah pengelolaan perumahan, mencakup wilayah metropolis serta pedesaan. Memandang alokasinya bisa diamani memang Wilayah Bandung Utara berperan penting kepada kawasan sekelilingnya. Wilayah Bandung Utara melewati empat (4) wilayah administratif kota dan kabupaten yang berbeda, ialah Kota Bandung, Kabupaten Bandung,

Kabupaten Bandung Barat dan Kota Cimahi.

Masalah IMB tidak ada habisnya, sebab pelanggaranpelanggaran yang dilakukan masih terjadi dilapangan walaupun sudah ada Peraturan Daerah. Namun masalah ini membuat penasaran bagaimana proses implmentasi kebijakan berjalan sesuai aturan atau bias jadi malah kebanyakan pelanggaran yang muncul seperti mendirikan bangunan tidak ada izin dari pemerintah setempat dan tidak memiliki IMB.

Berikut ini Data Izin Mendirikan Bangunan (IMB) yang dikeluarkan oleh Kecamatan Cimenyan daerah Kawasan Bandung Utara.

Tabel 1.1

Data IMB

\begin{tabular}{|c|c|l|}
\hline $\begin{array}{c}\text { Jumlah } \\
\text { Bangunan }\end{array}$ & $\begin{array}{c}\text { Jumlah } \\
\text { Bangunan } \\
\text { BER IMB }\end{array}$ & \multicolumn{1}{|c|}{ Ket } \\
\hline 11,225 & 1,099 & $\begin{array}{l}\text { IMB yang } \\
\text { dikeluarkan } \\
\text { oleh } \\
\text { Kecamatan } \\
\text { dengan Luas } \\
\text { Bangunan } \\
\text { Dibawah 250 } \\
\text { M }\end{array}$ \\
\hline
\end{tabular}

Sumber: Kecamatan Cimenyan (Buku Register Kecamatan)

Dengan melihat data yang ada IMB yang masih jauh dari kondisi nyata, karena dengan datang langsung kelapangan masih banyak dan perlu dilakukan peninjauan lebih dalam Implementasi Kebijakan Pemerintah Daerah.

Penelitian terdahulu mengenai Implementasi Kebijakan Kawasan Bandung Utara, pernah dilakukan oleh Muhamad Nur Afandi Tahun 2014 dengan menggunakan pokok bahasan penelitian yaitu mengenai Implementasi Kebijakan Pembangunan di Kawasan 
Bandung Utara dalam Perspektif Pembangunan yang Berwawasan Lingkungan, dari hasil penelitiannya yaitu akibat dari pemberian ijin bagi aktivitas pembangunan yang diperkirakan akan menimbulkan dampak pada masyarakat luas sehingga seharusnya melalui proses pendapat publik (public hearing) dan bahkan debat publik (public debate) tentang boleh tidaknya aktivitas pembangunan tersebut dilaksanakan oleh pemohon.

\section{TINJAUAN PUSTAKA}

Implementasi merupakan kejadian apa sesudah kebijakan perundangan disahkan, dala hal ini memasrahkan kekuasaan kepada salah satu agenda peraturan, fungsi ataupun satu model keluaran yang nyata Menurut Inu Kencana (2007: 56). Implementasi disini lebih pada keluaran yang didapat sesudah satu kebijakan perundangan disahkan dan sejauhmana kebijakan itu dilasanakan oleh berbagai pihak.

Para ahli menyebutkan diantaranya menurut Van Meter \& Van Horn sebenarnya implementasi adalah aksi sama perorangan, atasan, fraksi instansi penguasan ataupun partikelir yang dihadapkan kepada berhasilnya maksud-maksud yang sudah ditetapkan pada satu ketetapan terpilih. Instansi-instansi pemerintah menjalankan aktivitas negara yang mendorong akibat kepada anggota wilayah. Tetapi pelaksanaannya instansi penguasa kerapkali bertemu kegiatankegiatan dibawah instruksi dari perundang-undangan, sampai-sampai melahirkan khalayak tidak bisa buat menetapkan apa yang sebenarnya akan dilaksanakan dan dilajalnkan.

Keluarnya Peraturan dan kebijakan public dilandasi dari keperluan buat penanganan persoalan yang di publik. Kebijaksanaan masyarakat disahkan oleh tiap-tiap bagian, terpenting penguasa yang dititik berakat kepada pemuasan keperluan serta keinginan publik. Makna dari penerapan kebijaksanaan public menggambarkan salah satu jaringan yang sangat mengharuskan penerimaan maksud ataupun target dari hasil akhir dari aktivitas yang dilaksanakan penguasa.

Definisi dari Kebijakan yaitu bagaikan hubungan dasar agenda, pekerjaan, kelaksanaan, ketetapan, prilaku buat beraksi yang dilaksanakan oleh para pelaku, suatu hirarki buat penanganan persoalanan yang ada. Penentuan kebijaksanaan menggambarkan satu indikator utama buat institusi untuk menggapai sasaran (Iskandar, 2012).

Kesalahan atau kekurangan pada kebijakan public akan dapat diketahui setelah kebijakan public tersebut dilaksanakan, keberhasilan kebijakan public dapat dilihat dari dampak yang ditimbulkan sebagai hasil evaluasi atas pelaksanaan suatu kebijakan (Rohman, 2016).

Kebijakan public dalam teori Merilee S. Grindle dipengaruhi oleh dua variable besar yaitu kandungan kebijaksanaan dan bagian dari pelaksanaan. Variable termaktub mencakup sampai kemana keperluan fraksi target tertuang pada kandungan kebijaksanaan dan model fungsi yang didapat oleh golongan sasaran, sejauhmana perlihan yang diharapkan dari satu kebijaksanaan, baik itu penempatan lokasi prosedut telah benar, apa suatu kebijaksanaan sudah menuturkan pelaksananya secara detail dan apak suatu agenda dibantu sama sarana dan prasarana yang lengkap (Subarsono, 2011).

Kebijakan public menurut Thomas R Dye yang disadur dalam Islamy (2009:19) menjabarkan bahwa prosedur masyarakat sebagai "is whatever government choose to do or not to do". Ketentuan ini memusatkan sebenarnya dalam kebijakan publik ialah tentang kenyataan "tindakan" tidak menggambarkan pemberitahuan kemauan penguasa ataupun pemimpin masyarakat satu-satunya. Kebijakan publik merupakan hasil dari keputusan- 
keputusan yang dibuat oleh individu maupun organisasi.

Bangunan merupakan sesuatu yang terletak diatas tanah didirikan dan diletakan dalam suatu lingkungan sebagian atau seluruhnya. Bangunan ini berupa gedung, rumah atau sejenisnya yang dibangun diatas tanah atau diperairan.

Kebijakan public bisa diartikan seperti rangkaian aktivitas terjaga, teratur, dan terpola yang dilaksanakan sama penguasa serta membawa beberapa bagian yang mempunyai kebutuhan dalam bagian-bagian definitif hingga buat mengevektifkan ketentuan masyarakat dibutuhkan aktivitas kemasyarakatan, penerapan serta pemeriksaan strategi secara menyeluruh.

\section{METODE PENELITIAN}

Penelitian Implementasi kebijakan public menggunakan desain penelitian metode kualitatif yaitu penelitian yang dimaksudkan untuk menggambarkan sesuatu yang dilihat dan diamati apa adanya dilapangan yang terjadi. segala sesuatu yang berkaitan dengan implementasi kebijakan public di Kawasan Bandung Utara (KBU) tepatnya di Kecamatan Cimenyan. Penelitian ini pada umumnya memakai ancangan empiris rasional yaitu informasi ditampung cocok beserta maksud dengan masuk akal ditata menggunakan simpulan untuk ditarik datanya yang telah terkumpul.

Penggunaan penelitian jenis deskriptif ini didasarkan pada sejumlah keunggulan dan kekuatan metode deskriptif, diantaranya menggambarkan siatuasi salah satu fenomena yang nyata dalam keadaan terbatas. Mengenali suatu informasi memberitahukan indikasiindikasi pada sebuah kejadian, mendapatkan informasi yang membuktikan penampilan pada sesuatu kenyataan dan menampung informasi yang bisa memberitahukan kenyataan dari suatu aspirasi ataupun konstitusi (Widodo, 2000:19).
Sumber informasi ini untuk penelitian kualititatif menggunakan informan dan rujukan terikat sama persoalanan observasi yang oleh penelaah dikira bisa membagikan penjelasan serta keterangan yang valid. Observasi ini narasumber wajib memahami sejauhmana strategi itu dilaksanakan di dilapangan, apa sesuai dengan apa yang diatur dalam kebijakan tersebut atau tidak. . Adapun cara yang dipakai buat memilih narasumber pada observasi sebagaimana dijelaskan dalam kutipan buku (Sugiyono, 2007: 52), bahwa beserta cara penulis masuk web sosial tertentu, melaksanakan penelitian serta konsultasi pada mereka yang dianggap mengetahui mengenai kondisi kemasyarakat itu.

\section{HASIL DAN PEMBAHASAN}

Implementasi kebijakan tidak terlaksana secara benar sebab minimnya pemasayrakatan dari pemerintah pada publik sehingga dalam membuat IMB pemohon masih belum mengetahui ada aturan Perda Prov. Jabar Nomor 2/2016.

Faktor yang menyebabkan kesulitan adalah ketika membuat IMB harus membuat dulu rekomendasi sampai ke Gubernur atau pemerintah Provinsi Jawabarat dan SOP belum jelas. Faktor berikutnya adalah ribet dan lama menunggu proses pembuatan rekomendasi itu sendiri sehingga pengajuan IMB menjadi lama.

Dengan memperbanyak sosialisasi agar kebijakan pembuatan IMB yang berpengaruh terhadap Kawasan Bandung Utara dapat diminimalisir dan tertata untuk pembanguanan. Pembangunan yang dimaksud bisa skala besar maupun skala kecil, untuk masyarakat setempat harus ada pembeda untuk perizinan antara izin mendirikan bangunan untuk masyarakat penduduk asli/ pribumi yang sudah bertahun - tahun tinggal di lokasi tersebut dengan pengembang perumahan ataupun konsultan perumahan.

Menurut Edwards III, bahwa pelaksana kebijakan dapat diartikan 
seperti tahapan proses dari suatu kebijakan, letaknya ada di antara tingkatan penyusunan kebijakan dan konsekuensi yang ditimbulkan oleh kebijakan tersebut. Dan dari bagianbagian diduga kuat berkontriubusi pada pelaksanaan kebijakan yaitu hubungan, sumber daya, catatan ataupun pendapat pelakasana serta sistem birokrasi, ke-4 bagian tersebut berdampak kepada penerapan ketetapan, baik itu langsung mapun tidak langsung dan tiap-tiap bagian sama-sama mempengaruhi kepada bagian yang berbeda (Wahyudi, 2016)

Kebijakan aturan Perda Propinsi Jawa Barat Nomor 2 Tahun 2016 menjadi perbincangan yang menarik oleh penulis, karena perda ini diturunkan langsung dari Gubernur. Pelaksana dilapangan untuk menindaklanjuti proses IMB terkendala oleh aturan. Hasil wawancara dengan petugas dilapangan menyatakan bahwa pemerintah kecamatan hanya bertugas sebagai pengingat dan melaporkan. Salah satu contoh ketika ada warga ingin membuat rumah akan tetapi belum membuat/ memproses ijinnya tetapi sudah terlanjur ada kegiatan dilokasi atau bahkan sudah berdiri bangunan tetapi belum ada ijinnya, maka pihak kecamatan melalui SATPOL PP hanya memberikan teguran saja. Sedangkan ketika para investor yang ingin membuat perumahan-perumahan atau kaplingan maka bisa ditindak lebih tegas dan akan diberhentikan proses pembanguananya bahkan bisa jadi ditutup sementara sampai izin IMB keluar.

Sangat membutuhkan sosialisasi dari pihak pemangku kebijakan kepada tim pelaksana dilapangan, karena agar memudahkan jalan birokrasi dan kebijakan publik berjalan lancar sesuai ketentuan. Sosialisasi dari Pemerintah Provinsi Jawa Barat kepada Kabupaten dan dilanjutkan ke semua wilayah di Kecamatan kemudian semua Desa binaan mewajibkan sosialisasi untuk pembuatan IMB agar masyarakat kecil bisa juga dengan mudah membuat IMB. Karena selama ini masyarakat masih sangat awam terhadap IMB sehingga sangat membutuhkan sosialisasi tersebut. Jika sosialisasi berjalan lancar maka masyarakat setidaknya akan segera mengurus IMB sesuai prosedur yang berlaku sesuai Perda.

Perda Prof. Jabar No. 2/2016 dalam pasal 5 ayat 1 itu bahwa ada kata wajib memperoleh rekomendasi, dalam pasal tersebut berarti jika akan membuat IMB harus terlebih dahulu dibuatkan rekomendasi dari Gubernur, karena IMB tidak akan keluar/ diproses baik di tingkat kecamatan ataupun ditingkat kabupaten apabila belum ada rekomendasi gubernur.

Dalam hal penegakan Perda Provinsi tersebut sanksi apa saja yang telah di kenakan kepada masyarakat atau kepada pelanggar untuk wilayah Kecamatan Cimenyan. Terlihat dilapangan bahwa jika seperti perumahan-perumahan yang besar atau lahan yang besar pasti diberhentikan sesuai dengan peraturan yang ada dan berlaku. Akan tetapi jika ke masyarakat yang memiliki lahan yang kecil tidak ada sanksi hanya teguran saja. Demikian sangat jelas dengan aturan-arturan yang berlaku dari Gubernur tingkat Provinsi, Bupati tingkat Kabupaten dan Camat dari tingkat Kecamatan yang harus diselesaikan dan aturan itu tetap ada karena mengikat hukum dasar untuk mendirikan bangunan.

Bagi pelanggar yang belum memiliki IMB selama ini hanya sampai pemberhentian saja belum ada tindakan sampai pembongkaran. Karena dalam aturan Perda itu sangat jelas jika melanggar bisa sampai dibongkar. Berarti salama ini belum ada di wilayah Kecamatan Cimenyan sampai pembongkaran kepada bangunanbangunan liar yang tidak memiliki IMB atau tidak berizin.

Pembahasan untuk pelanggar dalam pembongkaran itu biasanya tidak ada karena diserahkan kembali penindakan-penindakan bukan dari Pemerintah Kecamatan akan tetapi langsung dari Satpol PP yang ada di 
dinas, baik tingkat kabupaten maupun tingkat provinsi yang akan menindaknya. Lalu akan memberikan penjelasan dari Dinas terkait bahwa diberhentikan sementara karena belum ada izinnya dan mereka juga membuka status segel dengan membuktikan surat perjanjian tidak menjalankan pembangunan kembali.

Tindak lanjut dari perda sendiri berdasarkan hasil peneliti dilapangan baiknya dilihat dalam Perda tersebut bahwa untuk penataan ruang harus benarbenar pada wilayah KBU, seharusnya sudah stop/berhenti melakukan aktivitas membangun seperti gedung, atau perumahan dan kavling jika dilihat dari penataan ruang.

Tetapi kenyataanya khusus diwilayah Kecamatan Cimenyan berdasarkan observasi dilapangan menunjukkan bahwa semakin banyak pembangunan terutama bangunan perumahan-perumahan atau kaplingkaplingan yang semakin merebak, sementara diperda itu sendiri penataan ruangnya sudah sangat jelas harus terkendali, jangan sampai pembangunan terus berjalan tanpa terkendali yang akan mengakbatkan dampak terhadap lingkungan yang tidak baik.

Adapun laporan dari tingkat Kecamatan dari unsur keamanan dan ketertiban hanya memberikan surat teguran atau surat pemberitahuan dan untuk selanjutnya menyerahkan kepada Pemerintah Kabupaten Bandung melalui dinas instansi yang terkait, karena phak pemerintah kecamatan tidak ada kewenangan untuk menutup atau memberi sanki kepada para pelanggar perizinan. Untuk hal-hal yang melanggar aturan akan dikeluarkan surat oleh pihak pemerintah kabupaten atau Provinsi terutama yang berkaitan dengan sanki dari pelanggaran itu sendiri.

\section{KESIMPULAN}

Implementasi kebijakan masih masih terkendala dengan minimnya pemasyarakatan dari aspek penguasan pada publik hingga untuk membuat IMB publik masih belum tahu peraturan yang berlaku.

Faktor yang menyebabkan kesulitan adalah ketika membuat IMB sebelum pengajuan berkas IMB harus terlebih dahulu memproses rekomendasi gubernur, hal ini dirasakan oleh para pemohon IMB yang berada dikawasan Bandung Utara merasa sulit, ribet, dan lama, serta peraturan masih belum jelas dengan sanksi yang berlaku. Masyarakat mengeluhkan hal tersebut apalagi, dengan lahan yang kecil harus izin samapi kepada Gubernur.

Kesimpulan hasil penelitian Kebijakan Pengendalian Kawasan Bandung Utara dalam Pembuatan IMB di Kecamatan Cimenyan ditemukan bahwa sebagai kawasan strategis dimana pola tata ruangnya dengan kebijakan Perda No 2 tahun 2016 harus benar-benar efektif dilaksanakan. Karena jika kebijakan Perda Provinsi tersebut tidak dilaksanakan akan berakibat fatal terhadap lingkungan sekitar sehingga tidak akan terkendali Kawasan Bandung Utara dengan banyaknya pembuat perumahan atau investor yang akan membangun perumahan semakin banyak.

\section{Dengan adanya Peraturan} Provinsi tersebut setidaknya ada pengendalian lahan untuk tidak terlalu cepat berkembangnya. Sehingga Perda itu sangat efektif dilaksanakan baik untuk pemangku kepentingan maupun pembuat kebijakan itu sendiri. Jadi kebijakan aturan rekomendasi Gubernur itu adalah salah satu untuk mengendalikan agar tidak terlalu cepat pengalih fungsian lahan karena lahan KBU merupakan lahan yang memang harus di manfaatkan agar warga masyarakat tidak seenaknya mengalihfungsikan lahan tersebut. Seperti pertanian, lahan hijau, perkebunan, yang dekat dengan pemukiman warga agar tetap asri dan hijau di lahan Kabupaten Bandung Utara khususnya daerah Kecamatan Cimenyan yang merupakan daerah resapan air, baik untuk pertanian maupun untuk menjaga lingkungan. 


\begin{abstract}
Peneliti menyarankan harus adanya kebijakan khusus bagi masyarakat yang berada di Kawasan Bandung Utara secara turun temurun dan hanya memiliki lahan yang sangat terbatas untuk membuat IMB tanpa harus melalui proses Rekomendasi Gubernur, tetapi tetap memperhatikan Rencana Tata Ruang Wilayah (RT RW), sehingga memudahkan warga untuk membuat izin mendirikan bangunan agar warga dapat tertib meminimalisir terjadinya pembangunan illegal dan tata ruang kawasan tertata rapih serta tidak merusak Kawasan Bandung Utara. Harus adanya sosialisasi tentang kebijakan Perda Provinsi Nomor 2 Tahun 2016, sehingga masyarakat khususnya masyarakat menengah kebawah karena selama ini masih menemukan kendala dilapangan bahwa dalam pembuatan IMB di wilayah Bandung Utara terutama di Kecaatan Cimenyan terlalu ribet dan lama tanpa mengetahui dengan pasti penyebab dari lama tersebut, karena mereka beranggapan membuat IMB di Kawasan Bandung Utara sama saja dengan membuat IMB di wilayah lain (diluar Kawasan Bandung Utara).

Hal ini yang menyebabkan banyaknya pemilik bangunan tempat tinggal / rumah yang sudah berdiri dan dihuni bertahun-tahun tetapi belum memiliki Ijin Mendirikan Bangunan (IMB).
\end{abstract}

\section{DAFTAR PUSTAKA}

Agustino, L. (2014). Dasar-Dasar Kebijakan Publik. Bandung: Alfabeta.

Islamy, I. (2010). Prinsip-Prinsip Perumusan Kebijakan Negara. Jakarta: Bumi Aksara.

Nazar, F., Mochtar, S., dkk. (2021). Analisis Implementasi Kebijakan Pengendalian Pembuangan Limbah Cair Domestik ke Badan Air Penerima di Kabupaten Purwakarta.

Rohman, A.T. (2016). Implementasi Kebijakanmelalui Kualitas Pelayanan Penerimaan Pajak Daerah dan Implementasinya terhadap Kepuasan Masyarakat di Dinas Pendapatan Kabupaten Kuningan. Bandung: Universitas Pasundan. Retrieved from http://repository.unpas.ac.id

Subarsono. (2011). Kebijakan Publik: Konsep, Teori, dan Aplikasi. Jogyakarta: Pustaka Pelajar.

Sugiyono, (2013). Metode Penelitian dan Pendidikan Pendekatan Kuantitatif, Kualitatif, dan $R \& D$ Bandung: Alfabeta.

Wahab, S.A. (2010). Pengantar Analisis Implementasi Kebijakan Negara. Jakarta: Rineka Cipta.

Wahyudi A (2016) Implementasi Rencana Strategis Badan Pemberdayaan Masyarakat dan Desa dalam upaya pengembangan Badan Usaha Milik desa di Kabupaten Kotawaringin Barat. Jurnal Ilmiah Administrasi Publik Retrieved from http://ejournalfia.ub.ac.id

Widodo, Joko. (2007). Analisa Kebijakan Publik. Malang: Bayu Media Publishing 